\title{
SOSYAL MEDYA KULLANICILARININ MARKA FARKINDALIK DÜZEYLERINE GÖRE SOSYAL SORUMLULUK PROJE FARKINDALIKLARI ARASINDAKI FARKLILIKLARININ BELIRLENMESİ: Eti Kurumsal Sosyal Sorumluluk Projeleri Üzerine Bir Araştırma
}

Sabiha KILIÇ

Kübra Müge ÇAKARÖZ ${ }^{2}$

Atıf/O): Çakaröz, Kübra Müge (2016). Sosyal Medya Kullanıcılarnnın Marka Farkındalık Düzeylerine Göre Sosyal Sorumluluk Proje Farkındalıkları Arasındaki Farklılıklarn Belirlenmesi: Eti Kurumsal Sosyal Sorumluluk Projeleri Üzerine Bir Araştırma, Hitit Üniversitesi Sosyal Bilimler Enstitüsü Dergisi, Yıl 9, Sayı 2, Aralık 2016, ss. 585-610

Özet: Günümüz tüketicileri sadece ürün ve hizmet kalitesiyle yetinmemekte bunun yanı sıra tüketici tercihlerinde kurumsal imaj ve marka imajinı da göz önünde bulundurmaktadirlar. Bu nedenle işletmelerin tüketici zihninde yer edinmek ve kalıcı olmak için çeşitli pazarlama stratejileri geliştirmeleri gerekmektedir. Bu stratejilerden birisi de sosyal sorumluluk projeleridir. Araştırmanın amact sosyal medya kullanıclarinın marka farkindalık düzeylerine göre sosyal sorumluluk projeleri farkındalık düzeyleri arasındaki farklılıklan belirlemektir. Bu amaçla çalışmada demografik değiş̧enlerin yarattığ algı farklılıkları değerlendirilmiştir. Araştırmanin temel varsayımı marka farkındalık düzeyi ve sosyal sorumluluk farkındalık düzeyinin demografik faktörlere ve haberdar olunan iletişim mecralarına göre farklılık gösterdiğidir. Araştırmanın amacı ve temel varsayımı çerçevesinde geliştirilen hipotezler Bağımsız Örneklem T Testi, One-way ANOVA Parametrik Testi ve Post-Hoc Testleri kullanılarak analiz edilmiştir. Anket yöntemi ile elde edilen verilerin analizinde tanımlayıcı istatistikler kullanılmıştır.

Anahtar Kelimeler: Kurumsal Sosyal Sorumluluk, Marka Farkindalığl, Kurumsal Sosyal Sorumluluk, Sosyal Medya.

Makale Geliş Tarihi: 18.03.2016/ Makale Kabul Tarihi: 29.11.2016

1 Doç. Dr., Hitit Üniversitesi, İktisadi ve İdari Bilimler Fakültesi, İşletme Bölümü, e-posta: sabihakilic@hitit.edu.tr

2 Arş. Gör., Hitit Üniversitesi, İktisadi ve İdari Bilimler Fakültesi, İşletme Bölümü, e-posta: kmugedaldal@hitit.edu.tr 


\section{Determining The Differences Among Soctal Responsibility Project Awareness Of Social Media Users According To Their Brand Awareness Level: A Study On Eti Institutional Social Responsibility Projects}

Citation/(): Çakaröz, Kübra Müge (2016). Determining The Differences Among Socıal Responsibility Project Awareness Of Soctal Media Users According To Their Brand Awareness Level: A Study On Eti Institutional Social Responsibility Projects, Hitit University Journal of Social Sciences Institute, Year 9, Issue 2, December 2016, pp. 585-610

Abstract: For today's costumers the quality of the product or service is not enough, besides that corporate image and brand image is considerable on consumer preferences. Because of that business develop vary marketing strategies for being permanent and getting in consumer mind. One of these strategy is social responsibility projects. The purpose of this studyis to determine the differences between social responsibility projects awarenes level according to the brand awareness level of social media users. For this purpose the perceptional differences caused by demografic factors were evaluated.The basic assumption of this research is that brand awereness level and social responsibility Project awereness level vary depend on demographics and communication media.

After hypotesis were improved by using the purposes of and also the basic assumption of the research, they are analyzed by Independent Sample T Test, One Way ANOVA Parametric Test and Post- Hoc Test.Descriptive statistics are applied to organizethe data which are taken from the survey.

Keywords: Social Responsibility, Brand Awereness, Corporate Social Responsibility, Social Media.

\section{GÍRIŞ}

Rekabetin artmasıla birlikte, işletmelerin sadece tüketici beklentileri doğrultusunda ürün sunmaları ya da sadece işletme çıkarlarını gözeterek karlılığa odaklanmaları yeterli olamamaktadır. Toplum bilincinin artmasıla tüketiciler işletmelerden toplum refahını artıracak faaliyetlerde bulunarak sosyal sorumluklarını yerine getirmelerini beklemektedirler. Son yıllarda bilinçli tüketicilerin sayısının artması ile bireysel faydaların yanı sıra toplumsal faydalar da ürün tercihinde etkili hale gelmiştir. Söz konusu değişimler, tüketicilerin ihtiyaçlarını ve beklentilerini etkileyerek işletmelerin sosyal sorumluluk alanına daha fazla ağırlık vermelerine neden olmuştur (Şener, 1996: 35).

İşletmelerin sosyal sorumluluklarını yerine getirirken marka imajını ve marka değerini artırmaya yönelik faaliyetlerde bulunmaları, kurumsal sosyal sorumluluk uygulamalarının bir pazarlama stratejisine dönüşmesini 
sağlamıştır. Hızla değişen dünyada işletmelerinin sürdürülebilirliklerini devam ettirebilmeleri tüketicilerin sadece somut ihtiyaçlarını değil soyut istek ve ihtiyaçlarını da göz önünde bulundurarak değişime ayak uydurmaları ile mümkündür. Tüketicilere farkl1, güvenilir, kaliteli ürünler sunarak tüketicinin karar vermesini kolaylaştıran ve tüketicinin zihninde yer edinen işletmeler sadık müşteriler elde ederek rakiplerinden üstün hale gelebilmektedirler. Bu durum güçlü bir markaya sahip olmakla mümkündür. Dolayısıyla işletmeler, tüketicilerin dikkatini çekerek markalarına yönelik farkındalık yaratmayı ve sadık müşteri grupları oluşturmayı amaçlamalıdırlar (Elitok,2003:103). Bu nedenle çalışmanın amacı sosyal medya kullanıcılarının marka farkındalık düzeylerine göre sosyal sorumluluk proje farkındalıkları arasındaki farklılıkları belirleyebilmektir. Bu amaç doğrultusunda aşağıdaki bölümlerde öncelikle marka farkındalığı ve sosyal sorumluluk kavramlarına dair ayrıntılı bilgilere yer verilmiştir.

\section{MARKA FARKINDALIĞI}

Farkında olmaktan türetilmiş olan "farkındalık" kelimesi; beyinde ve akılda edinilen bilgiler vasitasıyla bir durumun, olgunun ya da cismin varlığından haberdar olmayı ifade etmektedir. Farkındalık, zihinsel süreçler içerisinde anlatılabilen, sanal ya da soyut düşünmenin gerekli olduğu bir durumdur (Yıldırım, 2010: 98). Marka farkındalığına dair literatürde çok çeşitli tanımlar yer almaktadır. Marka farkındalığı, potansiyel müşterilerin, belirli bir ürün kategorisindeki markayı bilmesi ve hatırlaması olarak tanımlanmaktadır (İslamoğlu ve Firat,2011:58). Başka bir tanıma göre, tüketicilerin zihninde yer alan bir markanın varlığının gücüdür (Erdil ve Uzun, 2010: 221). Diğer bir tanıma göre ise marka farkındalığ "Markadan haberdar olma, tüketicinin zihninde markanın rakiplere göre kıyaslamalı olarak yeridir" şeklinde ifade edilmektedir (Uztuğ, 2003: 8).

Marka farkındalığı yaratma, marka için yapılan çalışmaların en önemli aşamalarındandır. Marka farkındalığında temel amaç, daha önce de bahsedildiği gibi farkındalık piramidinin en üst basamağında yer alan en üst düzeyde bir algılamaya ulaşmaktır. Mevcut bir marka için farkındalık piramidinde hangi düzeyde olduğunun tespiti yapılarak piramidin en üst düzeyine ulaşılmak istenir. Eğer ürün yeni ise çalışmaya ilk olarak farkındalık yaratılarak başlanılır. Farkındalık yaratmada dört temel unsur yer almaktadır. $\mathrm{Bu}$ unsurlar; diğer kurumsal olgularla bağlantı, aşinalık-düşkünlük, özün yansıması-taahhüt, markayı düşünüyor olmak şeklinde sıralanabilmektedir (Elitok, 2003: 105). 
Marka farkındalığı kavramı tüketicinin belleğinde marka ile ilgili bilgilerin olup olmadığını ya da ne derece güçlü olduğu ile ilgilenerek temelde marka tanınırlığını ve marka hatırlanırlığını içermektedir. Bununla birlikte tüketicilerin markaya dair bir fikir elde edebilmesi için farkındalığın oluşması gerekmektedir. Farkındalık ile ilgili yapılan araştırmalarda çeşitli farkındalık düzeyleri belirlenmiş ve farkındalık ölçümü yapılmaya çalışılmıştır. Farkındalık düzeylerinin ölçümünde kullanılan bu farkındalık düzeylerini tanınırlık, hatırlama, hatırlamada ilk olma, marka baskınlığı, marka bilgisi ve marka kanıs1 şeklinde sıralamak mümkündür (Uztuğ, 2003: 29-30).

Marka farkındalığı oluşturmak için çok sayıda pazarlama faaliyetinden yararlanılabilmektedir. Özellikle internet, televizyon ve dergi ve gazete gibi mecralarda reklam, reklam kuşağ1 sponsorluğu, ambalajlama, kültür-sanatspor-sosyal sorumluluk konularında sponsorluk, ilgili fuarlarda bulunma, gündem yaratarak pazarlama, gerilla pazarlama, kendi satış mağazasını oluşturma, perakende mağazalarda özel reyon kiralama gibi çeşitli pazarlama faaliyetleri ile tüketici ile iletişim kurmaya ve marka farkındalığı yaratılmaya çalış1lmaktadır ( Tığlı vd. 2007, ss:86) GFK araştırma şirketinin 2006 yılında yaptığı sponsorluk araştırmasında işletmelerin \%60,3'ünün sosyal sorumluluk projelerine destek verdikleri görülmektedir. Aynı araştırmada sponsorlukyapan işletmelerin \%63'ünün marka bilinirliğini artırmak, \%30'unun ise satışlarını artırmak için sponsorluk yaptıkları ortaya çıkmıştır. Araştırma sonuçları göz önünde bulundurulduğunda sosyal sorumluluk projelerinin marka farkındalık düzeyini artıracağı düşünülmektedir. Akademetre şirketinin 2006 yılında yapmış olduğu tüketici araştırmasında halkın büyük çoğunluğunun sağlık, eğitim, çevre ve sosyal konularda sponsorluk yapılmasını istediği ortaya çıkmıştır(Özçelik, 2006).

Çalışmanın bir sonraki bölümünde marka farkındalık düzeyini artırdığı düşünülen sosyal sorumluluk kavramına yer verilmektedir.

\section{SOSYAL SORUMLULUK}

Literatürde genel bir kavram olarak değerlendirilen kurumsal sosyal sorumluluk çeşitli fikir ve uygulamalardan oluşmaktadır. Kurumsal sosyal sorumluluk kavramı ile ilgili ilk görüş kurumların felaket anında yürüttüğü faaliyetler, ikinci görüşü kurumların ekonomik fonksiyonlarının yanı sıra gönüllü ya da kar amacı gütmeden gerçekleştirdikleri faaliyetler oluşturmaktadır. Bu faaliyetler halkla ilişkiler alanında kamu programları ve 
kriz yönetimi şeklinde yer almaktadır. (L'Etang ve Pieczka, 2002: 156).

İşletmelerin sürdürülebilirliklerini devam ettirebilmek için toplumun değişen ihtiyaçlarını göz önünde bulundurmaları gerekmektedir. Diğer bir ifadeyle işletmeler ekonomik faaliyetlerini gerçekleştirirken, toplum için zararlı veya olumsuz faaliyetleri sosyal dengeyi korumak için ortadan kaldırmalı ya da sosyal sorunları çözmek için kendi kaynaklarını aktararak toplumun rahatlığ ve sağlığına yönelik faaliyetlerde bulunmalıdırlar (Ölçer, 2001:24).

İşletmelerin sosyal sorumluluk alanları ile ilgili çeşitli sınıflandırmalar mevcut olmasına rağmen sosyal sorumluluk alanları birbirinden tamamen ayrıştırılamaz. İşletmelerin sosyal sorumluluk alanları işletme içi ve işletme dışı olarak oldukça genel bir ifadeyle ayrıştırılabileceği gibi, toplumsal çevreye yönelik sorumluluklar, tüketim ve tüketiciye yönelik sorumluluklar, çevreye yönelik sorumluluklar, sağlığa yönelik sorumluluklar, ekonomik gelişime yönelik sorumluluklar, eğitime yönelik sorumluluklar, sportif ve kültürel faaliyetlere yönelik sosyal sorumluluklar gibi çeşitli başlıklar altında da toplanabilir. Çeşitli başlıklara ayrılabilen sosyal sorumluluk türlerinin ilgi alanlarının da birbirinden kesin hatlarla ayrılması mümkün değildir ve bu ayrıştırmanın yanı sıra önemli olan tüm alanların birbirinin tamamlayıcısı olarak görülmesidir (Şener, 1996:16-45).

Sosyal sorumluluk alanında Türkiye'nin önemli problemlerinin çözümü için projeler gerçekleştiren pek çok marka ve şirket etkili projeleri ile hem markalarına olumlu katkılar sağlamakta, hem de ülke problemlerinin çözümüne yardımcı olmaktadırlar. Ülkemizde sosyal sorumluluk alanında büyük yatırımlar yapan ve etkinlikler düzenleyen markalardan birisi Eti'dir. Eti markasının günümüzde halen devam etmekte olan 5 sosyal sorumluluk projesi bulunmaktadır. Bu projelerin isimlerini; Sarı Bisiklet Projesi, Eti Çocuk Tiyatrosu, Eti Burçak WWF İşbirliği, Eti Çocuk Vapuru, ve Eti ÇEKÜL Kültür Elçileri olarak sıralayabiliriz (http://www.etietieti.com/bizden_etkinlikler. aspx). Çalışmanın bir sonraki bölümünde kurumsal sosyal sorumluk ve marka farkındalığına ilişkin literatür incelemesi yer almaktadır.

\section{LİTERATÜR İNCELEMESI}

Literatürde sosyal sorumluluk ve marka farkındalığına ilişkin çok sayıda çalışma yer almaktadır ancak her iki kavramı birlikte inceleyen çalışmaların sayısı oldukça sınırlıdır. Sosyal sorumluluk ve marka farkındalığ kavramlarını Tığlı, Pirtini ve Çelik 2007 yılında yapmış oldukları çalışmada 
birlikte incelemişlerdir. Çalışmada sosyal sorumluluk kampanyalarının marka imajına, marka farkındalığına ve gençlerin tüketici davranışlarına etkileri ölçülmüştür. Çalışmada sonuç olarak sosyal sorumluluk projelerinin genç tüketicilerin marka farkındalığı ve marka bağlılığını olumlu şekilde etkilediği ancak sosyal sorumluluk projelerinin genç tüketicilerin marka satın alma ya da marka değiştirme kararları üzerinde yeterince etkili olmadığı görülmüştür(Tığl1, Pirtini ve Çelik, 2007).

İncesu 2011 yılında yapmış olduğu çalışmasında, sosyal sorumluluk projelerinin marka farkındalığına etkisini araştırmış ve bu doğrultuda Türkiye'de yapılan örnek çalışmaları incelemiştir. Çalışma sonucunda işletmelerin varlıklarını sürdürebilmeleri ve farkındalıklarını artırabilmeleri için toplum sorunlarına, toplumu oluşturan bireylere, doğaya ve küresel değişime karşı duyarlı olmaları gerektiği belirlenmiştir(İncesu, 2011).

Akkoyunlu ve Kalyoncuoğlu 2014 yılında yapmış oldukları çalışmalarında kurumsal sosyal sorumluluk projelerinin marka algısı üzerine etkisini incelemiler ve demografik değişkenlerin yarattığı alg1 farklılıklarını ortaya koymuşlardır. Yapılan analizler sonucunda sosyal sorumluluk projelerinin marka algısını etkilediği ve demografik faktörlere göre anlamlı farklılıklar bulunduğu görülmüştür. Ayrıca sosyal sorumluluk projelerinin en yüksek düzeyde etkilediği marka denkliği faktörünün marka farkındalığı olduğu tespit edilmiştir(Akkoyunlu ve Kalyoncuoğlu, 2014).

Deneçli tarafından 2015 yılında yapılan çalışmada, sosyal sorumluluk projelerinin marka farkındalığına etkisi ölçülmüştür. Çalışmanın sonucunda sosyal sorumluluk projesini gerçekleştiren markayla ilgili marka farkındalığının, projeden haberdar olan tüketicilerde anlamlı düzeyde daha yüksek olduğu ortaya çıkmıştır(Deneçli, 2015).

Nigel Pope ise 1998 yılında yapmış olduğu çalışmasında sponsorluk aktivitelerinin sürdürülebilir olması gerektiğine değinmiştir. Satış grafiğinde artışın süreklilik ile sağlanabileceğini ifade etmiştir(Pope, 1998).

Toplu, 2009yılında yapmış olduğu çalışmasında kültür sanat sponsorluklarının marka farkındalığına olan etkisini belirleyebilmek için farklı sektörlerde faaliyet gösteren işletmelerle mülakatlar gerçekleştirmiştir. Çalışmada, kültür-sanat sponsorluklarının toplumların gelişebilmesi, markaların yaşayabilmesi, marka farkındalıklarının uzun süreli olabilmesi ve marka bağlılığının oluşabilmesi için sürdürülebilir olması gerektiği sonucuna ulaş1mıştır(Toplu, 20019). 


\section{YÖNTEM}

Sosyal medya kullanıcılarının sosyal sorumluluk projelerine yönelik farkındalık düzeyi farkl11ıklarını markaların farkındalık düzeylerine göre belirlemeye yönelik bu çalışmanın ana kütlesini Türkiye'de yaşayan ve Facebook, Twitter ve LinkedIn sosyal medya sitelerine üye olan kullanıcılar oluşturmaktadır. Ülkemizde Facebook sitesinin 40 milyon, Twitter sitesinin 8 milyon ve LinkedIn sitesinin 4 milyon aktif üyesi bulunmaktadır (Digitalage, 2014). Çalışmanın ana kütlesini 52 milyon aktif sosyal medya üyesi oluşturmaktadır. Ana kütle varyansı tahmin edilememektedir. Bu verilere göre çalışmanın örnek hacmi oranlar yoluyla örnekleme yöntemine göre 220 olarak hesaplanmıştır. Hatalı anketlerinde olabileceği dikkate alınarak uygulanan 250 anketten geçerli olan 239 anket değerlendirmeye alınmıştır. Anketler 18 yaş ve üstü bireylere uygulanmıştır.

Araştırmada kullanılan veriler anket tekniği ile toplanmıştır. Birincil verilere ulaşmak amacıyla kullanılan online anket formu üç bölümden oluşmaktadır. Birinci bölüm katılımcıların cinsiyet, yaş, eğitim, gelir gibi demografik özellikleri ile sosyal sorumluluk projelerinin görüldüğü iletişim mecralarının belirlenmesine yönelik çoktan seçmeli 5 soruladan oluşmaktadır. İkinci bölüm katılımcıların ETİ markasının sosyal sorumluluk projeleri olan Sarı Bisiklet, Eti Çocuk Tiyatrosu, Eti Burçak WWF İşbirliği, Eti ÇEKÜL Kültür Elçileri ve Eti Çocuk Vapuru projelerine ilişkin farkındalık düzeylerini belirlemeye yönelik 1 ve 5 arasında değişen beşli Likert ölçeğine göre sıralanmış 5 proje isminden oluşmaktadır. Üçüncü bölüm katılımcıların Eti markasına ilişkin marka farkındalık düzeylerini belirlemeye yönelik "Kesinlikle Katılıyorum" ve "Kesinlikle Katılmıyorum" arasında değişen beşli Likert ölçeğine göre sıralanmış 14 ifadeden oluşmaktadır. İfadelerin belirlenmesinde (Tosun, 2010) ve (Franzen, 1999) çalışmalarından faydalanılmıştır. Aşağıdaki bölümde araştırmanın amacı ve temel varsayımına uygun olarak geliştirilen araştırma modeli yer almaktadir.

\section{A. Araştırmanın Model ve Hipotezleri}

Araştırmada anket çalışması ile sosyal medya kullanıcılarının marka farkındalık düzeylerine göre sosyal sorumluluk projeleri farkındalık düzeyleri arasında farklılık olup olmadığı belirlenmeye çalışılmıştır. Bu çerçevede sosyal medya kullanıcılarının marka farkındalığı düzeyleri ile sosyal sorumluluk projeleri farkındalık düzeyleri arasında anlamlı bir farklılık olup olmadığ analiz edilmiştir. Araştırmada, ölçekler ve alt boyutlar arasındaki farklılıkların 
ortaya konulması amaçlanmaktadır. Bu amaçla oluşturulan araştırma modeli aşağıdaki gibidir:
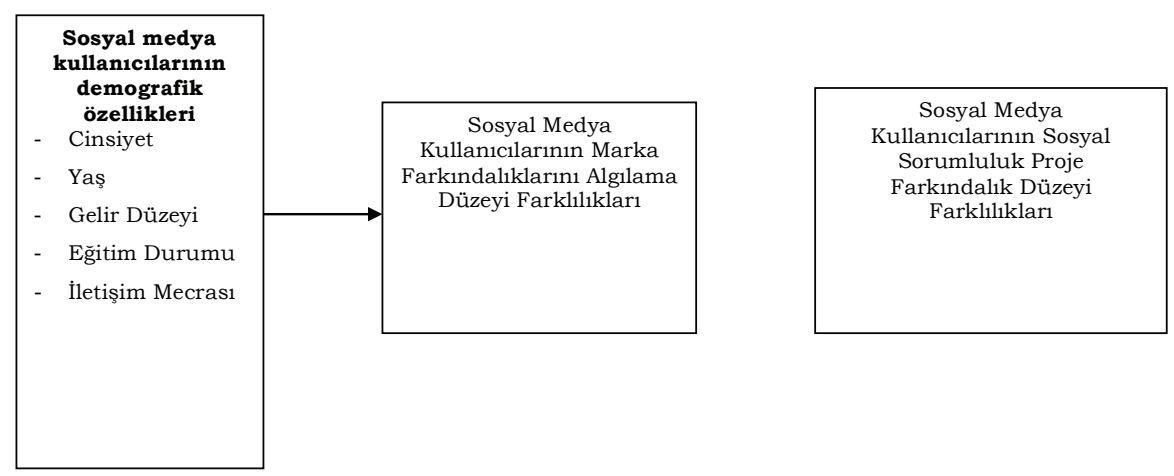

Şekil 1: Sosyal Medya Kullanıcılarının Demografik Özelliklerine Göre Marka Farkındalıklarını Algılama Düzeyi Farklılıklarına Göre Sosyal Sorumluluk Proje Farkındalık Düzeyi Farklılıklarına İlişkin Kavramsal Model

Şekil 1'deki kavramsal modele göre sosyal medya kullanıcılarının marka farkındalıklarını algılama düzeyleri sahip oldukları demografik özelliklere göre farklılık göstermektedir. Bu alg1 farklılığı ise sosyal medya kullanıcılarının markaların gerçekleştirdikleri sosyal sorumluluk projelerini algilama farkındalıkları arasında farklılıklara neden olmaktadır. Çalışmanın uygulama kısmı yukarıda oluşturulan model çerçevesinde gerçekleştirilmiştir. Belirlenen amaçlar doğrultusunda test edilen hipotezler aşağıdaki gibidir:

$\mathrm{H}_{1}$ : Sosyal medya kullanıcılarının cinsiyetlerine göre marka farkındalığını algılama düzeyleri ve dolayısıyla da sosyal sorumluluk projeleri farkındalık düzeyleri arasında farklılık vardır.

$\mathrm{H}_{2}$ : Sosyal medya kullanıcılarının yaşlarına göre marka farkındalığını algılama düzeyleri ve dolayısıyla da sosyal sorumluluk projeleri farkındalık düzeyleri arasında farklılık vardır.

$\mathrm{H}_{3}$ : Sosyal medya kullanıcılarının eğitim durumlarına göre marka farkındalığını algılama düzeyleri ve dolayısıyla da sosyal sorumluluk projeleri farkındalık düzeyleri arasında farklılık vardır.

$\mathrm{H}_{4}$ : Sosyal medya kullanıcılarının gelir düzeylerine göre marka farkındalığını algılama düzeyleri ve dolayısıyla da sosyal sorumluluk projeleri farkındalık düzeyleri arasında farklılık vardır. 
$\mathrm{H}_{5}$ : Sosyal medya kullanıcılarının sosyal sorumluluk uygulamalarından haberdar oldukları iletişim mecrasına göre marka farkındalığını algılama düzeyleri ve dolayısıyla da sosyal sorumluluk projeleri farkındalık düzeyleri arasında farklılık vardır.

\section{B. Araştırmadan Elde Edilen Verilerin Analizi Ve Değerlendirilmesi}

Çalışmanın bu bölümünde araştırmadan elde edilen bulgular ve bunların değerlendirilmesi yer almaktadır. Araştırma verilerinin analizinde SPSS (Statistical Package for the Social Sciences) 17 Student-Pack programindan faydalanılmıştır.

Veri analizinde ilk olarak; araştırmaya katılan sosyal medya kullanıcılarının demografik bilgilerine ilişkin bulgu ve yorumlara yer verilmiştir. Bunun yanı sıra araştırmadaki her bir ölçeğin güvenilirlik değerleri (Cronbachalpha) hesaplanmıştır. Sosyal medya kullanıcılarının marka farkındalık düzeyleri ve sosyal sorumluluk projeleri farkındalık düzeyleri farklılıklarını belirlemek amacıyla Bağımsız Örneklem T Testi,One-way ANOVA Parametrik Testi ve Post-Hoc Testleri yapılmıştır. Araştırma verileri gizlilik esası çerçevesinde değerlendirilmiştir.

\section{Ankete Katılanların Demografik Özelliklerine İlişkin Bulgular}

Demografik özellikler başlığ altında incelenen bulgular, katılımcıların cinsiyeti, yaşı, eğitim durumu, gelir düzeyi ve sosyal sorumluluk projelerinden haberdar oldukları iletişim mecralarını içermektedir.

Tablo 1: Katılımc1ların Demografik Özellikleri

\begin{tabular}{|c|c|c|c|c|c|}
\hline Cinsiyet & $\mathbf{N}$ & $\mathbf{\%}$ & $\mathbf{G e l i r}$ & $\mathbf{N}$ & $\mathbf{\%}$ \\
\hline Kadın & 150 & 62.8 & 1500 TL ve Alt1 & 65 & 27.2 \\
\hline Erkek & 89 & 37.2 & $1500-2000$ TL Aras1 & 50 & 20.9 \\
\hline Toplam & 239 & 100 & $2000-3000$ TL Aras1 & 63 & 26.4 \\
\hline Yaş & $\mathbf{N}$ & $\mathbf{\%}$ & 3000 TL ve Üzeri & 61 & 25.5. \\
\hline 18-25 Yaş Aras1 & 60 & 25.1 & Toplam & 239 & 100 \\
\hline 26-30 Yaş Aras1 & 60 & 25.1 & Medeni Hal & $\mathbf{N}$ & $\%$ \\
\hline 31-35 Yaş Aras1 & 51 & 21.3 & Evli & 96 & 40 \\
\hline 36-40 Yaş Aras1 & 26 & 10.9 & Bekar & 143 & 60 \\
\hline 40 Yaş ve Üzeri & 42 & 17.6 & İletişim Mecrasi & $\mathbf{N}$ & $\%$ \\
\hline Toplam & 239 & 100 & İnternet & 67 & 28,0 \\
\hline Eğitim & $\mathbf{N}$ & $\mathbf{\%}$ & Televizyon & 136 & 56,9 \\
\hline Lise & 47 & 9.5 & Gazete/Dergi & 12 & 5,0 \\
\hline Lisans & 135 & 52.3 & Ürün Ambalajlar1 & 17 & 7,1 \\
\hline Lisansüstü & 57 & 28.2 & Eş/Dost & 7 & 2,9 \\
\hline Toplam & 239 & 100 & Toplam & 239 & 100,0 \\
\hline
\end{tabular}


Tablo 1 incelendiğinde araştırmaya katılan katılımcıların \%62.8'inin kadın \%37.2'inin erkek olduğu ve bunların \%60’nın evli olduğu görülmektedir. Katılımcıların yaklaşık olarak \%75’i 25 yaşın üzerindedir. Katılımcıların \%80’i lisans veya lisansüstü eğitim düzeyine sahiptir. Katılımcıların \%73'ünün aylık geliri 1.500 TL'nin üzerindedir. Tablo 1 incelendiğinde araştırmaya katılan katılımcıların \%28'inin internet aracılığıla, \%56,9'unun televizyon aracılığıyla, \%5’inin gazete/dergi aracılığıyla Eti Markasının sosyal sorumluluk projelerinin varlığından haberdar oldukları görülmektedir.

\section{Kullanılan Ölçeklerin Güvenilirlik Analizleri}

Araştırmanın amaçları doğrultusunda geliştirilen araştırma hipotezlerini test etmeye başlamadan önce verilerin güvenilirlik ve geçerlilik açısından değerlendirilmesi gerekmektedir. Bu sebeple, araştırma hipotezleri test edilmeden önce güvenilirlik ve geçerlilik analizleri yapılmış, ölçeklerin güvenilirlikleri içsel tutarlılık yöntemi ile belirlenmiştir. İçsel tutarlılık yönteminin bir uygulaması da "alfa katsayısı"dır. Alfa katsayısı ölçeğin güvenilirliğini test etmede en yaygın kullanılan yöntem olup, sıfır ve bir arasında değişen rakamlar alır. Araştırmada kullanılan ölçeğin de güvenilirliğinden bahsedebilmek için alfa katsayısının \%70 ve üzerinde olması gerekmektedir (Hair vd., 1998: 118). Araştırma amaçları kapsamında oluşturulan anket formunun alfa katsayısı \%92,0 olarak hesaplanmıştır.

\section{E. Marka Farkındalık Düzeyi Ölçeğine Yönelik Tanımlayıcı İstatistikler}

Tanımlayıcı istatistikler, değişkenin sıklık dağılımını, oransal dağılımını, birikimli dağılımını, ortalamasını, standart sapmasını, varyansını, değişme katsayısını, çarpıklığını ve basıklığını içerir. Bütün bu kavramları tanımlayıcı istatistikler olarak değerlendirmemiz mümkündür. Çünkü tanımlayıcı analiz, değişkenlerin yapısını veya karakteristiğini tanımlamakta ve veriler üzerinde herhangi bir analiz yürütmemektedir (Nakip, 2003: 236). Çalışmanın bu bölümünde araştırma kapsamında kullanılan ölçeklerde yer alan ifadelere ilişkin yukarıda adı geçen tanımlayıcı istatistiklerden ortalama, standart sapma, varyans, çarpıklık ve basıklık değerleri gözlem değerlerinin normal dağılım varsayımlarını karşılama durumu ortaya konulmaya çalışılmıştır. 
Tablo 2: Marka Farkındalık Düzeyi Ölçeğine Yönelik Tanımlayıcı İstatistikler

\begin{tabular}{lcrrrr}
\hline Madde & $\mathbf{N}$ & Ortalama & Standart Sapma & Çarp1kl1k & \multicolumn{1}{c}{ Basıklik } \\
\hline 1 & 239 & 4,1046 & 1,14199 & $-1,470$ & 1,473 \\
2 & 239 & 3,6569 & 1,15203 &,- 630 &,- 343 \\
3 & 239 & 3,7155 & 1,01802 &,- 369 &,- 278 \\
\hline 4 & 239 & 3,4435 & 1,15407 &,- 465 &,- 551 \\
\hline 5 & 239 & 3,7029 & 1,13001 &,- 787 &, 069 \\
6 & 239 & 2,8703 & 1,22813 &, 016 & $-1,026$ \\
\hline 7 & 239 & 3,4770 & 1,23945 &,- 528 &,- 692 \\
8 & 239 & 2,9833 & 1,10372 &,- 175 &,- 780 \\
9 & 239 & 3,8787 & 1,10286 &,- 989 &, 478 \\
10 & 239 & 3,6276 & 1,09594 &,- 532 &,- 391 \\
11 & 239 & 3,4812 & 1,14801 &,- 651 &,- 280 \\
12 & 239 & 3,6569 & 1,04090 &,- 582 &,- 190 \\
13 & 239 & 3,4184 & 1,20601 &,- 473 &,- 526 \\
14 & 239 & 2,9121 & 1,26550 &, 003 & $-1,073$ \\
\hline
\end{tabular}

Marka farkındalık düzeyi ifadelerine verilen cevapların ortalama değerlerine bakıldığında 4,10 ile 2,87 arasında değiştiği görülmektedir. Ortalama merkez eğilim ölçüsü olan standart sapma değerlerine bakıldığında ise en büyük standart sapma değerinin 1,27, en küçük standart sapma değerinin 1,02 olduğu görülmektedir. Veri setindeki gözlemlerin normal dağılım varsayımını karşılayıp karşılamadığını anlamak amacıyla çarpıklık ve basıklık değerleri incelenmiştir. İstatistik literatüründe sonuçların yansız ve doğru tahminlerde bulunabilmesi için çarpıklık değerlerinin \pm 2 ve basıklık değerlerinin \pm 7 değer aralığında olması gerektirdiği ifade edilmektedir (Bollen, 1998: 266-267). Tablo incelendiğinde veri setindeki gözlemlere ilişkin çarpıklık ve basıklık değerlerinin istenilen değerler arasında yer aldığ görülmektedir.

\section{F. Araştırma Hipotezlerinin Test Edilmesi}

Araştırmanın bu bölümünde, araştırmanın amaç ve varsayımı doğrultusunda, daha önceden belirlenmiş olan hipotezler test edilmiştir.

\section{G. Demografik Değişkenlere Göre Marka Farkındalık Düzeyi ve Sosyal Sorumluluk Proje Farkındalık Düzeyi Farklılıklarına İlişkin Tanımlayıcı İstatistikler}

Araştırmanın bu bölümünde katılımcıların demografik değişkenlere göre marka farkındalık düzeyleri ve dolayısıyla da sosyal sorumluluk proje farkındalık düzeyleri arasındaki farklılıklar varyans analizi yardımıyla sınanmış, anlamlı olduğu belirlenen ilişkiler Tukey Testi ve tanımlayıcı istatistikler yardımıyla incelenerek istatistiksel olarak yorumlanmıştır. Tukey Testi, varyans analizi sonucunda gruplar arasında bir fark bulunmuşsa, farklılığın hangi gruplardan kaynaklandığının bulunmasını sağlamaktadır (Antalyalı, 2005: 135). 
Tablo 5: Cinsiyete Göre Sosyal Medya Kullanıcılarının Marka Farkındalık Düzeyine İlişkin T Testi Sonuçları

\begin{tabular}{|c|c|c|c|c|c|c|c|}
\hline & & $\mathrm{N}$ & $\bar{X}$ & $\mathrm{~s}$ & $\mathrm{~T}$ & $\mathrm{~F}$ & $\mathrm{P}$ \\
\hline \multirow{2}{*}{ Tanıma } & Kadın & 150 & 3,9578 & 88175 & 2,765 & \multirow{2}{*}{5,020} & \multirow{2}{*}{,026 } \\
\hline & Erkek & 89 & 3,5918 & 1,14895 & 2,587 & & \\
\hline \multirow{2}{*}{ Hatırlama } & Kadın & 150 & 3,7367 & ,93172 & 3,289 & \multirow{2}{*}{,038 } & \multirow{2}{*}{,845 } \\
\hline & Erkek & 89 & 3,3146 & 1,00392 & 3,226 & & \\
\hline \multirow{2}{*}{ Baskınlık } & Kadin & 150 & 3,2633 & 1,02436 &,- 133 & \multirow{2}{*}{2,339} & \multirow{2}{*}{, 128} \\
\hline & Erkek & 89 & 3,2809 & ,91687 &,- 137 & & \\
\hline \multirow{2}{*}{ Bilgi } & Kadın & 150 & 3,5067 & ,93624 & 1,330 & \multirow{2}{*}{1,630} & \multirow{2}{*}{, 203 } \\
\hline & Erkek & 89 & 3,3446 & ,86668 & 1,356 & & \\
\hline \multirow{2}{*}{ Kanı } & Kadın & 150 & 3,5950 & 1,02144 & 1,015 & \multirow{2}{*}{4,452} & \multirow{2}{*}{,036 } \\
\hline & Erkek & 89 & 3,4635 & ,87057 & 1,057 & & \\
\hline
\end{tabular}

Tablo 5'de katılımcıların cinsiyetleri itibariyle marka farkındalığı düzeyleri arasında fark olup olmadığını tespit etmek amacıyla yapılmış olan bağımsız örneklem $\mathrm{t}$ testi sonuçları görülmektedir. Tablo 5 incelendiğinde $\mathrm{p}<0,05$ anlamlılık düzeyinde "marka farkındalığı alt boyutlarından hatırlama, baskınlık ve bilgi yönünden kadınlar ile erkekler arasında anlamlı bir farklılık yoktur" denilebilir. Ancak p<0,05 anlamlılık düzeyinde "marka farkındalığı alt boyutlarından tanıma ve kanı yönünden cinsiyete göre kadınlar ve erkekler arasında anlamlı bir farklılık vardır" denilebilir. Tanıma ve kanı alt boyutlarına ilişkin ortalamalara bakıldığında ise, marka farkındalığı alt boyutlarından tanıma ve kanı yönünden kadın katılımcıların erkek katılımcılara oranla marka farkındalık düzeylerinin daha yüksek olduğu görülmektedir. 
Tablo 6: Yaşa Göre Sosyal Medya Kullanıcılarının Marka Farkındalık Düzeylerine İlişkin Varyans Analizi Sonuçları

\begin{tabular}{|c|c|c|c|c|c|c|c|}
\hline & & $\mathrm{N}$ & $\bar{X}$ & S & $\mathrm{F}$ & $P$ & $\begin{array}{l}\text { Anlamli } \\
\text { Farklılık } \\
\text { (Tukey) }\end{array}$ \\
\hline \multirow{6}{*}{ 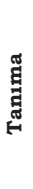 } & 18-25 Yaș Aras 1 & 60 & 3,4556 & 1,18682 & \multirow{6}{*}{3,403} & \multirow{6}{*}{, 010} & \multirow{6}{*}{$1<2$} \\
\hline & 26-30 Yaș Arası & 60 & 4,0944 & ,97055 & & & \\
\hline & 31-35 Yaș Aras1 & 51 & 3,9216 & ,85007 & & & \\
\hline & 36-40 Yaș Arası & 26 & 3,7692 & ,71036 & & & \\
\hline & 40 Yaş ve Üzeri & 42 & 3,8651 & ,97408 & & & \\
\hline & Toplam & 239 & 3,8215 & 1,00313 & & & \\
\hline \multirow{6}{*}{ 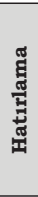 } & 18-25 Yaș Arası & 60 & 3,1500 & ,98849 & \multirow{6}{*}{,814 } & \multirow{6}{*}{, 518} & \\
\hline & 26-30 Yaş Arası & 60 & 3,4083 & ,87572 & & & \\
\hline & 31-35 Yaş Arası & 51 & 3,3235 & 1,03355 & & & \\
\hline & 36-40 Yaş Arası & 26 & 3,0769 & ,99692 & & & \\
\hline & 40 Yaş ve Üzeri & 42 & 3,2976 & 1,05956 & & & \\
\hline & Toplam & 239 & 3,2699 & ,98378 & & & \\
\hline \multirow{6}{*}{ 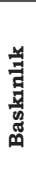 } & 18-25 Yaş Arası & 60 & 3,4250 & 1,04080 & \multirow{6}{*}{4,844} & \multirow{6}{*}{,001 } & \multirow{6}{*}{$\begin{array}{l}1<2 \\
4<2 \\
5<2\end{array}$} \\
\hline & 26-30 Yaş Arası & 60 & 3,9417 & ,78163 & & & \\
\hline & 31-35 Yaş Arası & 51 & 3,7157 & 1,06421 & & & \\
\hline & 36-40 Yaș Arası & 26 & 3,0962 & ,73511 & & & \\
\hline & 40 Yaș ve Üzeri & 42 & 3,4167 & ,99337 & & & \\
\hline & Toplam & 239 & 3,5795 & ,97874 & & & \\
\hline \multirow{6}{*}{$\overrightarrow{\text { b्p }}$} & 18-25 Yaș Arası & 60 & 3,0556 & 1,03456 & \multirow{6}{*}{5,140} & \multirow{6}{*}{,001 } & \multirow{6}{*}{$\begin{array}{l}1<2 \\
1<3\end{array}$} \\
\hline & 26-30 Yaș Arası & 60 & 3,7500 & ,78264 & & & \\
\hline & 31-35 Yaş Arası & 51 & 3,5948 &, 81463 & & & \\
\hline & 36-40 Yaş Arası & 26 & 3,4615 &, 81146 & & & \\
\hline & 40 Yaş ve Üzeri & 42 & 3,3810 & ,90038 & & & \\
\hline & Toplam & 239 & 3,4463 &, 91250 & & & \\
\hline \multirow{6}{*}{ 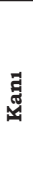 } & 18-25 Yaș Arası & 60 & 3,3167 & 1,15702 & \multirow{6}{*}{3,489} & \multirow{6}{*}{,009 } & \multirow{6}{*}{$1<2$} \\
\hline & 26-30 Yaș Arası & 60 & 3,9125 &, 77682 & & & \\
\hline & 31-35 Yaș Arası & 51 & 3,5343 & ,96179 & & & \\
\hline & 36-40 Yaș Arası & 26 & 3,3269 & ,72377 & & & \\
\hline & 40 Yaș ve Üzeri & 42 & 3,5000 & ,94514 & & & \\
\hline & Toplam & 239 & 3,5460 & 96823 & & & \\
\hline
\end{tabular}

Tablo 6'da katılımcıların yaşları itibariyle marka farkındalık düzeyleri arasında fark olup olmadığını tespit etmek amacıyla yapılmış olan tek yönlü ANOVA testi sonuçları görülmektedir. Tablo 6 incelendiğinde $p<0,05$ anlamlılık düzeyinde "marka farkındalığı alt boyutlarından hatırlama yönünden katılımcılar arasında anlamlı bir farklılık yoktur" denilebilir. Ancak $\mathrm{p}<0,05$ anlamlılık düzeyinde "marka farkındalığı alt boyutlarından tanıma, baskınlık, bilgi ve kanı yönünden yaşa göre katılımcılar arasında anlamlı farklılıklar vardır" denilebilir. Marka farkındalığı alt boyutlarından tanıma, baskınlık, bilgi ve kanı yönünden ortalamalara bakıldığında 26-30 yaş arasında yer alan katılımcıların marka farkındalık düzeylerinin 18-25 yaş arasında yer alan katılımcılardan daha yüksek olduğu görülmektedir. Ayrıca, baskınlık yönünden katılımcıların ortalamaları göz önüne alındığında 36-40 yaş aralığında ve 40 yaş ve üzerinde bulunan katılımcıların marka farkındalık düzeylerinin 26-30 yaş arasında yer alan katılımcılardan daha yüksek olduğu görülmektedir. 
Tablo 7: Eğitim Düzeyine Göre Sosyal Medya Kullanıcılarının Marka Farkındalık Düzeylerine İlişkin Varyans Analizi Sonuçları

\begin{tabular}{|c|c|c|c|c|c|c|c|}
\hline & & $\mathrm{N}$ & $\bar{X}$ & $\mathrm{~S}$ & $\mathrm{~F}$ & $\mathrm{P}$ & $\begin{array}{l}\text { Anlamlı } \\
\text { Farklilık } \\
\text { (Tukey) }\end{array}$ \\
\hline \multirow{4}{*}{ Tanima } & Lise & 47 & 3,5106 & ,90316 & \multirow{4}{*}{12,122} & \multirow{4}{*}{, 000} & \multirow{4}{*}{$\begin{array}{l}1<3 \\
2<3\end{array}$} \\
\hline & Lisans & 135 & 3,7062 & 1,06275 & & & \\
\hline & Lisansüstü & 57 & 4,3509 & ,71108 & & & \\
\hline & Toplam & 239 & 3,8215 & 1,00313 & & & \\
\hline \multirow{4}{*}{ Hatırlama } & Lise & 47 & 3,4787 & ,72948 & \multirow{4}{*}{10,236} & \multirow{4}{*}{, 000} & \multirow{4}{*}{$\begin{array}{l}1<3 \\
2<3\end{array}$} \\
\hline & Lisans & 135 & 3,4074 & ,98342 & & & \\
\hline & Lisansüstü & 57 & 4,0702 & ,99749 & & & \\
\hline & Toplam & 239 & 3,5795 & ,97874 & & & \\
\hline \multirow{4}{*}{ Baskınlık } & Lise & 47 & 3,4468 & ,80240 & \multirow{4}{*}{5,424} & \multirow{4}{*}{,005 } & \multirow{4}{*}{$2<3$} \\
\hline & Lisans & 135 & 3,1444 & 1,01824 & & & \\
\hline & Lisansüstü & 57 & 3,4211 & 1,00796 & & & \\
\hline & Toplam & 239 & 3,2699 & ,98378 & & & \\
\hline \multirow{4}{*}{ Bilgi } & Lise & 47 & 3,4752 & ,73801 & \multirow{4}{*}{2,564} & \multirow{4}{*}{,079 } & \\
\hline & Lisans & 135 & 3,3012 & ,95145 & & & \\
\hline & Lisansüstü & 57 & 3,7661 & ,87733 & & & \\
\hline & Toplam & 239 & 3,4463 & ,91250 & & & \\
\hline \multirow{4}{*}{ Kan1 } & Lise & 47 & 3,6330 & ,80226 & \multirow{4}{*}{4,357} & \multirow{4}{*}{, 014} & \multirow{4}{*}{$2<3$} \\
\hline & Lisans & 135 & 3,3963 & ,97084 & & & \\
\hline & Lisansüstü & 57 & 3,8289 & 1,02878 & & & \\
\hline & Toplam & 239 & 3,5460 & ,96823 & & & \\
\hline
\end{tabular}

Tablo 7'de katılımcıların eğitim düzeyleri itibariyle marka farkındalık düzeyleri arasında fark olup olmadığını tespit etmek amacıyla yapılmış olan tek yönlü ANOVA testi sonuçları görülmektedir. Tablo 7 incelendiğinde $\mathrm{p}<0,05$ anlamlılık düzeyinde "marka farkındalığı alt boyutlarından bilgi yönünden katılımcılar arasında anlamlı bir farklılık yoktur" denilebilir. Ancak $\mathrm{p}<0,05$ anlamlılık düzeyinde "marka farkındalığı alt boyutlarından tanıma, hatırlama, baskınlık ve kanı yönünden eğitim düzeyine göre katılımcılar arasında anlamlı farklılıklar vardır" denilebilir. Katılımciların eğitim düzeyine bağlı farkındalık düzeyi ortalamaları incelendiğinde lisans ve lisansüstü mezunu katılımcıların farkındalık düzeyi ortalamalarının lise mezunu katılımcılara oranla daha yüksek olduğu görülmektedir. 
Tablo 8: Gelir Düzeyine Göre Sosyal Medya Kullanıcılarının Marka Farkındalık Düzeylerine İlişkin Varyans Analizi Sonuçları

\begin{tabular}{|c|c|c|c|c|c|c|c|}
\hline & & $\mathrm{N}$ & $\bar{X}$ & $\mathrm{~S}$ & $\mathrm{~F}$ & $P$ & $\begin{array}{c}\text { Anlaml1 } \\
\text { Farklilık } \\
\text { (Tukey) }\end{array}$ \\
\hline \multirow{5}{*}{ Tanıma } & 1500 TL ve Alt1 & 65 & 3,8564 & 1,03409 & \multirow{5}{*}{1,582} & \multirow{5}{*}{, 194} & \\
\hline & $1500-2000$ TL Aras 1 & 50 & 3,8200 &, 73836 & & & \\
\hline & 2000-3000 TL Aras1 & 63 & 3,6138 & 1,17654 & & & \\
\hline & 3000 TL ve Üzeri & 61 & 4,0000 & ,94673 & & & \\
\hline & Toplam & 239 & 3,8215 & 1,00313 & & & \\
\hline \multirow{5}{*}{ Hatirlama } & 1500 TL ve Alt1 & 65 & 3,6000 & 1,10114 & \multirow{5}{*}{, 455 } & \multirow{5}{*}{, 714} & \\
\hline & $1500-2000$ TL Aras 1 & 50 & 3,5100 & ,90627 & & & \\
\hline & 2000-3000 TL Aras1 & 63 & 3,5079 & ,91797 & & & \\
\hline & 3000 TL ve Üzeri & 61 & 3,6885 & ,97110 & & & \\
\hline & Toplam & 239 & 3,5795 & ,97874 & & & \\
\hline \multirow{5}{*}{ Baskınlık } & 1500 TL ve Alt1 & 65 & 3,4359 & ,99813 & \multirow{5}{*}{1,058} & \multirow{5}{*}{,368 } & \\
\hline & 1500-2000 TL Aras 1 & 50 & 3,6400 & ,66271 & & & \\
\hline & 2000-3000 TL Aras1 & 63 & 3,4021 & 94501 & & & \\
\hline & 3000 TL ve Üzeri & 61 & 3,3443 & ,95640 & & & \\
\hline & Toplam & 239 & 3,4463 & ,91250 & & & \\
\hline \multirow{5}{*}{ Bilgi } & 1500 TL ve Alt1 & 65 & 3,3077 & ,99094 & \multirow{5}{*}{1,895} & \multirow{5}{*}{, 131} & \\
\hline & 1500-2000 TL Aras 1 & 50 & 3,5000 & ,86307 & & & \\
\hline & 2000-3000 TL Aras 1 & 63 & 3,0635 & ,96925 & & & \\
\hline & 3000 TL ve Üzeri & 61 & 3,2541 & 1,05918 & & & \\
\hline & Toplam & 239 & 3,2699 & ,98378 & & & \\
\hline \multirow{5}{*}{ Kanı } & 1500 TL ve Alt1 & 65 & 3,5462 & 1,08424 & \multirow{5}{*}{, 225} & \multirow{5}{*}{,879 } & \\
\hline & $1500-2000$ TL Aras 1 & 50 & 3,6400 & ,80995 & & & \\
\hline & 2000-3000 TL Aras1 & 63 & 3,4960 & ,94238 & & & \\
\hline & 3000 TL ve Üzeri & 61 & 3,5205 & 1,00031 & & & \\
\hline & Toplam & 239 & 3,5460 & ,96823 & & & \\
\hline
\end{tabular}

Tablo 8'de katılımcıların gelir düzeyleri itibariyle marka farkındalık düzeyleri arasında fark olup olmadığını tespit etmek amacıyla yapılmış olan tek yönlü ANOVA testi sonuçları görülmektedir. Tablo 8 incelendiğinde $\mathrm{p}<0,05$ anlamlılık düzeyinde "marka farkındalığı alt boyutlarından tanıma, hatırlama, baskınlık, bilgi ve kanı yönünden farklı gelir düzeyine sahip katılımcılar arasında anlamlı bir farklılık yoktur" denilebilir. 
Tablo 9: Sosyal Sorumluluk Projelerinden Haberdar Oldukları İletişim Mecrasına Göre Sosyal Medya Kullanıcılarının Marka Farkındalık Düzeylerine İlişkin Varyans Analizi Sonuçları

\begin{tabular}{|c|c|c|c|c|c|c|c|}
\hline & & $\mathrm{N}$ & $\bar{X}$ & $\mathrm{~S}$ & $\mathrm{~F}$ & $\mathrm{P}$ & $\begin{array}{l}\text { Anlamlı } \\
\text { Farklılık } \\
\text { (Tukey) }\end{array}$ \\
\hline \multirow{6}{*}{ Tanıma } & İnternet & 67 & 3,7164 & 1,25831 & \multirow{6}{*}{, 568} & \multirow{6}{*}{,686 } & \\
\hline & Televizyon & 136 & 3,8971 & ,76928 & & & \\
\hline & Gazete ve Dergiler & 12 & 3,8333 & 1,22680 & & & \\
\hline & Ürün Ambalajları & 17 & 3,6078 & 1,49181 & & & \\
\hline & Tanıdık Eş-Dost & 7 & 3,8571 & ,32530 & & & \\
\hline & Toplam & 239 & 3,8215 & 1,00313 & & & \\
\hline \multirow{6}{*}{ Hatırlama } & Internet & 67 & 3,6716 & ,97915 & \multirow{6}{*}{2,901} & \multirow{6}{*}{,233 } & \\
\hline & Televizyon & 136 & 3,6654 & ,86721 & & & \\
\hline & Gazete ve Dergiler & 12 & 3,0417 & 1,07573 & & & \\
\hline & Ürün Ambalajları & 17 & 3,1765 & 1,43550 & & & \\
\hline & Tanıdık Eş-Dost & 7 & 2,9286 & 1,05785 & & & \\
\hline & Toplam & 239 & 3,5795 & ,97874 & & & \\
\hline \multirow{6}{*}{ Baskınlık } & İnternet & 67 & 3,3980 &, 78547 & \multirow{6}{*}{1,689} & \multirow{6}{*}{, 153} & \\
\hline & Televizyon & 136 & 3,4240 & ,94931 & & & \\
\hline & Gazete ve Dergiler & 12 & 4,0833 & ,66856 & & & \\
\hline & Ürün Ambalajları & 17 & 3,4706 & 1,17886 & & & \\
\hline & Tanıdık Eş-Dost & 7 & 3,1905 & ,71640 & & & \\
\hline & Toplam & 239 & 3,4463 & ,91250 & & & \\
\hline \multirow{6}{*}{ Bilgi } & İnternet & 67 & 3,2313 & ,90591 & \multirow{6}{*}{2,195} & \multirow{6}{*}{, 070} & \\
\hline & Televizyon & 136 & 3,2794 & 1,02337 & & & \\
\hline & Gazete ve Dergiler & 12 & 3,6667 & ,93744 & & & \\
\hline & Ürün Ambalajları & 17 & 3,4412 & ,96635 & & & \\
\hline & Tanıdık Eş-Dost & 7 & 2,3571 &, 55635 & & & \\
\hline & Toplam & 239 & 3,2699 & ,98378 & & & \\
\hline \multirow{6}{*}{ Kan1 } & İnternet & 67 & 3,5000 & ,88335 & \multirow{6}{*}{1,477} & \multirow{6}{*}{,210 } & \\
\hline & Televizyon & 136 & 3,5515 & ,99355 & & & \\
\hline & Gazete ve Dergiler & 12 & 4,1250 & ,85613 & & & \\
\hline & Ürün Ambalajları & 17 & 3,4412 & 1,22643 & & & \\
\hline & Tanıdık Eş-Dost & 7 & 3,1429 & ,34932 & & & \\
\hline & Toplam & 239 & 3,5460 & ,96823 & & & \\
\hline
\end{tabular}

Tablo 9'da katılımciların sosyal sorumluluk projelerinden haberdar oldukları iletişim mecraları itibariyle marka farkındalık düzeyleri arasında fark olup olmadığını tespit etmek amacıyla yapılmış olan tek yönlü ANOVA testi sonuçları görülmektedir. Tablo 9 incelendiğinde önemlilik değerlerinin \%5'den büyük olduğu görülmektedir. Dolayısıyla, "marka farkındalığı alt boyutlarından tanıma, hatırlama, baskınlık, bilgi ve kanı yönünden sosyal medya projelerinden haberdar olunan iletişim mecralarına göre katılımcılar arasında anlamlı bir farklılık yoktur" denilebilir. 
Tablo 10: Cinsiyete Göre Sosyal Medya Kullanıcılarının Sosyal Sorumluluk Projeleri Farkındalık Düzeylerine İlişkin T Testi Sonuçları

\begin{tabular}{|c|c|c|c|c|c|c|c|}
\hline & & $\mathrm{N}$ & $\bar{X}$ & S & $\mathrm{t}$ & $\mathrm{F}$ & $\mathrm{P}$ \\
\hline \multirow{2}{*}{ Sar1 Bisiklet } & Kadın & 150 & 2,8000 & 1,50168 & 1,562 & \multirow{2}{*}{12,797} & \multirow{2}{*}{,000 } \\
\hline & Erkek & 89 & 2,5056 & 1,23513 & 1,641 & & \\
\hline \multirow{2}{*}{$\begin{array}{l}\text { Eti Çocuk } \\
\text { Tiyatrosu }\end{array}$} & Kadın & 150 & 2,8400 & 1,38098 &, 545 & \multirow{2}{*}{,679 } & \multirow{2}{*}{,411 } \\
\hline & Erkek & 89 & 2,7416 & 1,29271 & ,555 & & \\
\hline \multirow{2}{*}{$\begin{array}{l}\text { Eti Burçak ve } \\
\text { WWF İşbirliği }\end{array}$} & Kadın & 150 & 3,0533 & 1,52292 & ,932 & \multirow{2}{*}{, 181} & \multirow{2}{*}{,671 } \\
\hline & Erkek & 89 & 2,8652 & 1,48623 & ,938 & & \\
\hline \multirow{2}{*}{$\begin{array}{l}\text { Çekül Kültür } \\
\text { Elçileri }\end{array}$} & Kadın & 150 & 2,4067 & 1,30614 &,- 311 & \multirow{2}{*}{,022 } & \multirow{2}{*}{,882 } \\
\hline & Erkek & 89 & 2,4607 & 1,27970 &,- 313 & & \\
\hline \multirow{2}{*}{ Eti Çocuk Vapuru } & Kadın & 150 & 2,3800 & 1,29361 & $-1,597$ & \multirow{2}{*}{,070 } & \multirow{2}{*}{,792 } \\
\hline & Erkek & 89 & 2,6629 & 1,37298 & $-1,573$ & & \\
\hline
\end{tabular}

Tablo 10'da katılımciların cinsiyetleri itibariyle sosyal sorumluluk projeleri farkındalık düzeyleri arasında fark olup olmadığını tespit etmek amacıyla yapılmış olan Bağımsız Örneklem T Testi sonuçları görülmektedir. Tablo 10 incelendiğinde önemlilik değerlerinin \%5'den büyük olduğu görülmektedir. Dolayısıyla "Eti Çocuk Tiyatrosu, Eti Burçak ve WWF İşbirliği, Eti ÇEKüL Kültür Elçileri ve Eti Çocuk Vapuru kurumsal sosyal sorumluluk projeleri farkındalık düzeyleri yönünden kadınlar ile erkekler arasında anlamlı bir farklılık yoktur" denilebilir. Ancak p<0,05 anlamlılık düzeyinde "Sarı bisiklet projesi farkındalık düzeyleri yönünden kadınlar ve erkekler arasında anlamlı farklılık vardır" denilebilir. Sarı Bisiklet projesi farkındalıklarına ilişkin ortalamalara bakıldığında, kadın katılımcıların erkek katılımcılara oranla sosyal sorumluluk projeleri farkındalık düzeylerinin daha yüksek olduğu görülmektedir. 
Tablo 11: Yaşa Göre Sosyal Medya Kullanıcılarının Sosyal Sorumluluk Projeleri Farkındalık Düzeylerine İlişkin Varyans Analizi Sonuçları

\begin{tabular}{|c|c|c|c|c|c|c|c|}
\hline & & $\mathrm{N}$ & $\bar{X}$ & $\mathrm{~S}$ & $\mathrm{~F}$ & $\mathrm{P}$ & $\begin{array}{c}\text { Anlamlı } \\
\text { Farklılık } \\
\text { (Tukey) }\end{array}$ \\
\hline \multirow{6}{*}{ Sar1 Bisiklet } & 18-25 Yaş Arası & 60 & 2,9333 & 1,31312 & \multirow{6}{*}{, 719} & \multirow{6}{*}{, 542} & \\
\hline & 26-30 Yaş Arası & 60 & 2,7500 & 1,56903 & & & \\
\hline & 31-35 Yaş Aras1 & 51 & 2,8431 & 1,57953 & & & \\
\hline & 36-40 Yaş Arası & 26 & 2,3462 & 1,01754 & & & \\
\hline & 40 Yaş ve Üzeri & 42 & 2,2857 & 1,23537 & & & \\
\hline & Toplam & 239 & 2,6904 & 1,41286 & & & \\
\hline \multirow{6}{*}{$\begin{array}{l}\text { Eti Çocuk } \\
\text { Tiyatrosu }\end{array}$} & 18-25 Yaş Arası & 60 & 2,8000 & 1,17603 & \multirow{6}{*}{6,007} & \multirow{6}{*}{, 001} & \multirow{6}{*}{$\begin{array}{l}4<1 \\
4<2\end{array}$} \\
\hline & 26-30 Yaş Arası & 60 & 2,6500 & 1,54947 & & & \\
\hline & 31-35 Yaş Arası & 51 & 2,9020 & 1,37484 & & & \\
\hline & 36-40 Yaş Arası & 26 & 3,1538 & 1,46130 & & & \\
\hline & 40 Yaş ve Üzeri & 42 & 2,6905 & 1,15796 & & & \\
\hline & Toplam & 239 & 2,8033 & 1,34689 & & & \\
\hline \multirow{6}{*}{$\begin{array}{l}\text { Eti Burçak ve } \\
\text { WWF İşbirliği }\end{array}$} & 18-25 Yaş Arası & 60 & 2,8500 & 1,52743 & \multirow{6}{*}{15,101} & \multirow{6}{*}{, 000} & \multirow{6}{*}{$\begin{array}{l}1<2 \\
3<1 \\
3<2 \\
4<2\end{array}$} \\
\hline & 26-30 Yaş Arası & 60 & 2,7167 & 1,51927 & & & \\
\hline & 31-35 Yaş Arası & 51 & 2,9608 & 1,52264 & & & \\
\hline & 36-40 Yaş Arası & 26 & 3,5769 & 1,62906 & & & \\
\hline & 40 Yaş ve Üzeri & 42 & 3,2143 & 1,29795 & & & \\
\hline & Toplam & 239 & 2,9833 & 1,50898 & & & \\
\hline \multirow{6}{*}{$\begin{array}{l}\text { Çekül Kültür } \\
\text { Elçileri }\end{array}$} & 18-25 Yaş Arası & 60 & 2,5833 & 1,18310 & \multirow{6}{*}{, 284} & \multirow{6}{*}{, 837} & \\
\hline & 26-30 Yaş Arası & 60 & 2,3333 & 1,42218 & & & \\
\hline & 31-35 Yaş Aras1 & 51 & 2,3922 & 1,32783 & & & \\
\hline & 36-40 Yaş Arası & 26 & 1,9615 & 1,14824 & & & \\
\hline & 40 Yaş ve Üzeri & 42 & 2,6667 & 1,26234 & & & \\
\hline & Toplam & 239 & 2,4268 & 1,29392 & & & \\
\hline \multirow{6}{*}{$\begin{array}{l}\text { Eti Çocuk } \\
\text { Vapuru }\end{array}$} & 18-25 Yaş Arası & 60 & 2,8000 & 1,43562 & \multirow{6}{*}{1,184} & \multirow{6}{*}{,316 } & \\
\hline & 26-30 Yaş Aras1 & 60 & 2,4167 & 1,35661 & & & \\
\hline & 31-35 Yaş Arası & 51 & 2,1373 & 1,38592 & & & \\
\hline & 36-40 Yaş Aras1 & 26 & 2,5000 & 1,06771 & & & \\
\hline & 40 Yaş ve Üzeri & 42 & 2,5476 & 1,13056 & & & \\
\hline & Toplam & 239 & 2,4854 & 1,32795 & & & \\
\hline
\end{tabular}

Tablo 11'de katılımcıların yaşları itibariyle sosyal sorumluluk projeleri farkındalık düzeyleri arasında fark olup olmadığını tespit etmek amacıyla yapılmış olan tek yönlü ANOVA testi sonuçları görülmektedir. Tablo 11 incelendiğinde $\mathrm{p}<0,05$ anlamlılık düzeyinde "Katılımcıların yaşlarına göre Sarı Bisiklet, Çekül Kültür Elçileri, Eti Çocuk Vapuru sosyal sorumluluk projeleri farkındalık düzeyleri arasında anlamlı bir farklılık yoktur" denilebilir. Ancak $\mathrm{p}<0,05$ anlamlılık düzeyinde "Katılımcıların yaşlarına göre Eti Burçak ve WWF işbirliği, Eti Çocuk Tiyatrosu projeleri farkındalık düzeyleri arasında anlamlı farklıklar vardır" denilebilir. Eti Burçak ve WWF İşbirliği, Eti Çocuk Tiyatrosu, projelerine ilişkin farkındalık ortalamaları incelendiğinde, Eti Burçak ve WWF işbirliği, Eti Çocuk Tiyatrosu projelerinin 31-35 yaş arasında olan katılımcıların farkındalık düzeylerinin diğer gruplardan daha yüksek olduğu görülmektedir. 
Tablo 12: Eğitim Düzeyine Göre Sosyal Medya Kullanıcılarının Sosyal Sorumluluk Projeleri Farkındalık Düzeylerine İlişkin Varyans Analizi Sonuçları

\begin{tabular}{|c|c|c|c|c|c|c|c|}
\hline & & $\mathrm{N}$ & $\bar{X}$ & $\mathrm{~s}$ & $\mathrm{~F}$ & $\mathrm{p}$ & $\begin{array}{c}\text { Anlaml1 } \\
\text { Farklilik } \\
\text { (Tukey) }\end{array}$ \\
\hline \multirow{4}{*}{ Sar1 Bisiklet } & Lise & 47 & 2,8298 & 1,27380 & \multirow{4}{*}{1,445} & \multirow{4}{*}{,238 } & \\
\hline & Lisans & 135 & 2,5556 & 1,41245 & & & \\
\hline & Lisansüstü & 57 & 2,8947 & 1,50812 & & & \\
\hline & Toplam & 239 & 2,6904 & 1,41286 & & & \\
\hline \multirow{4}{*}{$\begin{array}{l}\text { Eti Çocuk } \\
\text { Tiyatrosu }\end{array}$} & Lise & 47 & 2,9149 & 1,28249 & \multirow{4}{*}{,271 } & \multirow{4}{*}{,763 } & \\
\hline & Lisans & 135 & 2,8000 & 1,29753 & & & \\
\hline & Lisansüstü & 57 & 2,7193 & 1,52074 & & & \\
\hline & Toplam & 239 & 2,8033 & 1,34689 & & & \\
\hline \multirow{4}{*}{$\begin{array}{l}\text { Eti Burçak ve WWF } \\
\text { İşbirliği }\end{array}$} & Lise & 47 & 3,4043 & 1,71514 & \multirow{4}{*}{3,290} & \multirow{4}{*}{,039 } & \multirow{4}{*}{$3<1$} \\
\hline & Lisans & 135 & 2,9778 & 1,42193 & & & \\
\hline & Lisansüstü & 57 & 2,6491 & 1,46983 & & & \\
\hline & Toplam & 239 & 2,9833 & 1,50898 & & & \\
\hline \multirow{4}{*}{$\begin{array}{l}\text { Çekül Kültür } \\
\text { Elçileri }\end{array}$} & Lise & 47 & 2,1702 & 1,32401 & \multirow{4}{*}{4,880} & \multirow{4}{*}{,008 } & \multirow{4}{*}{$\begin{array}{l}1<2 \\
3<2\end{array}$} \\
\hline & Lisans & 135 & 2,6519 & 1,30051 & & & \\
\hline & Lisansüstü & 57 & 2,1053 & 1,16011 & & & \\
\hline & Toplam & 239 & 2,4268 & 1,29392 & & & \\
\hline \multirow{4}{*}{ Eti Çocuk Vapuru } & Lise & 47 & 2,5532 & 1,45675 & \multirow{4}{*}{2,323} & \multirow{4}{*}{, 100 } & \\
\hline & Lisans & 135 & 2,6000 & 1,29983 & & & \\
\hline & Lisansüstü & 57 & 2,1579 & 1,25056 & & & \\
\hline & Toplam & 239 & 2,4854 & 1,32795 & & & \\
\hline
\end{tabular}

Tablo 12'de katılımcıların eğitim düzeyleri itibariyle sosyal sorumluluk projeleri farkındalık düzeyleri arasında fark olup olmadığını tespit etmek amacıyla yapılmış olan tek yönlü ANOVA testi sonuçları görülmektedir. Tablo 12 incelendiğinde $\mathrm{p}<0,05$ anlamlılık düzeyinde "katılımcıların eğitim düzeylerine göre Sarı Bisiklet, Eti Çocuk Tiyatrosu, Eti Çocuk Vapuru sosyal sorumluluk projeleri farkındalık düzeyleri arasında anlamlı bir farklılık yoktur" denilebilir. Ancak $\mathrm{p}<0,05$ anlamlılık düzeyinde "katılımcıların eğitim düzeylerine göre Eti Burçak ve WWF işbirliği ve Çekül Kültür Elçileri sosyal sorumluluk projeleri farkındalık düzeyleri arasında anlamlı bir farklılık vardır" denilebilir. Eti Burçak ve WWF İşbirliği, Çekül Kültür Elçileri projelerine ilişkin farkındalık ortalamaları incelendiğinde lisansüstü mezunlarının farkındalık ortalamalarının lise ve lisans mezunu katılımcılardan daha yüksek olduğu görülmektedir. 
Tablo 13: Gelir Düzeyine Göre Sosyal Medya Kullanıcılarının Sosyal Sorumluluk Projeleri Farkındalık Düzeylerine İlişkin Varyans Analizi Sonuçları

\begin{tabular}{|c|c|c|c|c|c|c|c|}
\hline & & $\mathrm{N}$ & $\bar{X}$ & $\mathrm{~S}$ & $\mathrm{~F}$ & $\mathrm{p}$ & $\begin{array}{c}\text { Anlamlı } \\
\text { Farklılık } \\
\text { (Tukey) }\end{array}$ \\
\hline \multirow{5}{*}{ Sar1 Bisiklet } & $1500 \mathrm{TL}$ ve Altı & 65 & 2,8154 & 1,43497 & \multirow{5}{*}{1,895} & \multirow{5}{*}{,112 } & \\
\hline & 1500-2000 TL Aras 1 & 50 & 2,6800 & 1,31615 & & & \\
\hline & 2000-3000 TL Aras1 & 63 & 2,7778 & 1,38476 & & & \\
\hline & 3000 TL ve Üzeri & 61 & 2,4754 & 1,50118 & & & \\
\hline & Toplam & 239 & 2,6904 & 1,41286 & & & \\
\hline \multirow{5}{*}{$\begin{array}{l}\text { Eti Çocuk } \\
\text { Tiyatrosu }\end{array}$} & 1500 TL ve Altı & 65 & 3,1077 & 1,32433 & \multirow{5}{*}{, 774} & \multirow{5}{*}{, 543} & \\
\hline & 1500-2000 TL Aras 1 & 50 & 3,1400 & 1,12504 & & & \\
\hline & 2000-3000 TL Aras1 & 63 & 2,7619 & 1,41095 & & & \\
\hline & 3000 TL ve Üzeri & 61 & 2,2459 & 1,31220 & & & \\
\hline & Toplam & 239 & 2,8033 & 1,34689 & & & \\
\hline \multirow{5}{*}{$\begin{array}{l}\text { Eti Burçak } \\
\text { ve WWF } \\
\text { İşbirliği }\end{array}$} & 1500 TL ve Altı & 65 & 3,1385 & 1,49872 & \multirow{5}{*}{1,867} & \multirow{5}{*}{, 117} & \\
\hline & 1500-2000 TL Aras1 & 50 & 4,0200 & 1,31692 & & & \\
\hline & 2000-3000 TL Aras 1 & 63 & 2,3810 & 1,34918 & & & \\
\hline & 3000 TL ve Üzeri & 61 & 2,5902 & 1,37085 & & & \\
\hline & Toplam & 239 & 2,9833 & 1,50898 & & & \\
\hline \multirow{5}{*}{$\begin{array}{l}\text { Çekül Kültür } \\
\text { Elçileri }\end{array}$} & $1500 \mathrm{TL}$ ve Altı & 65 & 2,4923 & 1,22631 & \multirow{5}{*}{1,521} & \multirow{5}{*}{, 197 } & \\
\hline & $1500-2000$ TL Arası & 50 & 2,2800 & 1,38564 & & & \\
\hline & 2000-3000 TL Aras & 63 & 2,4444 & 1,26718 & & & \\
\hline & 3000 TL ve Üzeri & 61 & 2,4590 & 1,33634 & & & \\
\hline & Toplam & 239 & 2,4268 & 1,29392 & & & \\
\hline \multirow{5}{*}{$\begin{array}{l}\text { Eti Çocuk } \\
\text { Vapuru }\end{array}$} & 1500 TL ve Alt1 & 65 & 2,6154 & 1,42184 & \multirow{5}{*}{1,806} & \multirow{5}{*}{, 128} & \\
\hline & 1500-2000 TL Aras 1 & 50 & 2,4600 & 1,21571 & & & \\
\hline & 2000-3000 TL Aras 1 & 63 & 2,6190 & 1,51794 & & & \\
\hline & 3000 TL ve Üzeri & 61 & 2,2295 & 1,07072 & & & \\
\hline & Toplam & 239 & 2,4854 & 1,32795 & & & \\
\hline
\end{tabular}

Tablo 13'desosyal medya kullanıcılarının gelir düzeyleri itibariyle sosyal sorumluluk projeleri farkındalık düzeyleri arasında fark olup olmadığını tespit etmek amacıyla yapılmış olan tek yönlü ANOVA testi sonuçları görülmektedir. Tablo 13 incelendiğinde önemlilik değerleri \%5'den büyük olduğu için "Katılımcıların gelir düzeylerine göre Sosyal sorumluluk projeleri farkındalık düzeyleri arasında anlamlı bir farklılık yoktur" denilebilir. 
Tablo 14: Sosyal Sorumluluk Projelerinden Haberdar Oldukları İletişim Mecrasına Göre Sosyal Medya Kullanıcılarının Sosyal Sorumluluk Projeleri Farkındalık Düzeylerine İlişkin Varyans Analizi Sonuçları

\begin{tabular}{|c|c|c|c|c|c|c|c|}
\hline & & $\mathrm{N}$ & $\bar{X}$ & $\mathrm{~S}$ & $\mathrm{~F}$ & $\mathrm{P}$ & $\begin{array}{c}\text { Anlamlı } \\
\text { Farklılık } \\
\text { (Tukey) }\end{array}$ \\
\hline \multirow{6}{*}{ Sar1 Bisiklet } & İnternet & 67 & 2,8806 & 1,33169 & \multirow{6}{*}{4,798} & \multirow{6}{*}{, 001} & \multirow{6}{*}{$\begin{array}{l}3<1 \\
4<1 \\
3<2 \\
4<2\end{array}$} \\
\hline & Televizyon & 136 & 2,8235 & 1,42404 & & & \\
\hline & Gazete ve Dergiler & 12 & 1,6667 & 1,30268 & & & \\
\hline & Ürün Ambalajları & 17 & 1,6471 & ,99632 & & & \\
\hline & Tanıdık Eş-Dost & 7 & 2,5714 & 1,51186 & & & \\
\hline & Toplam & 239 & 2,6904 & 1,41286 & & & \\
\hline \multirow{6}{*}{$\begin{array}{l}\text { Eti Çocuk } \\
\text { Tiyatrosu }\end{array}$} & Internet & 67 & 2,6269 & 1,16562 & \multirow{6}{*}{1,828} & \multirow{6}{*}{, 124} & \\
\hline & Televizyon & 136 & 2,9926 & 1,44272 & & & \\
\hline & Gazete ve Dergiler & 12 & 2,4167 & 1,44338 & & & \\
\hline & Ürün Ambalajları & 17 & 2,5294 & 1,06757 & & & \\
\hline & Tanıdık Eş-Dost & 7 & 2,1429 & 1,06904 & & & \\
\hline & Toplam & 239 & 2,8033 & 1,34689 & & & \\
\hline \multirow{6}{*}{$\begin{array}{l}\text { Eti Burçak ve } \\
\text { WWF İşbirliği }\end{array}$} & Internet & 67 & 2,8806 & 1,46186 & \multirow{6}{*}{1,072} & \multirow{6}{*}{, 371} & \\
\hline & Televizyon & 136 & 3,0588 & 1,48456 & & & \\
\hline & Gazete ve Dergiler & 12 & 3,3333 & 1,82574 & & & \\
\hline & Ürün Ambalajları & 17 & 2,9412 & 1,74895 & & & \\
\hline & Tanıdık Eş-Dost & 7 & 2,0000 & 1,15470 & & & \\
\hline & Toplam & 239 & 2,9833 & 1,50898 & & & \\
\hline \multirow{6}{*}{$\begin{array}{l}\text { Çekül Kültür } \\
\text { Elçileri }\end{array}$} & Internet & 67 & 2,7015 & 1,29117 & \multirow{6}{*}{2,853} & \multirow{6}{*}{,025 } & \multirow{6}{*}{$\begin{array}{l}1<3 \\
2<4\end{array}$} \\
\hline & Televizyon & 136 & 2,2279 & 1,19856 & & & \\
\hline & Gazete ve Dergiler & 12 & 3,0833 & 1,56428 & & & \\
\hline & Ürün Ambalajları & 17 & 2,2353 & 1,09141 & & & \\
\hline & Tanıdık Eş-Dost & 7 & 3,0000 & 2,23607 & & & \\
\hline & Toplam & 239 & 2,4268 & 1,29392 & & & \\
\hline \multirow{6}{*}{$\begin{array}{l}\text { Eti Çocuk } \\
\text { Vapuru }\end{array}$} & İnternet & 67 & 2,7164 & 1,36854 & \multirow{6}{*}{1,257} & \multirow{6}{*}{, 288} & \\
\hline & Televizyon & 136 & 2,4265 & 1,35336 & & & \\
\hline & Gazete ve Dergiler & 12 & 2,6667 & 1,30268 & & & \\
\hline & Ürün Ambalajları & 17 & 2,1765 & 1,01460 & & & \\
\hline & Tanıdık Eş-Dost & 7 & 1,8571 & ,89974 & & & \\
\hline & Toplam & 239 & 2,4854 & 1,32795 & & & \\
\hline
\end{tabular}

Tablo 14'de kat1lımciların sosyal sorumluluk projelerinden haberdar oldukları iletişim mecraları itibariyle sosyal sorumluluk projeleri farkındalık düzeyleri arasında fark olup olmadığını tespit etmek amacıyla yapılmış olan tek yönlü ANOVA testi sonuçları görülmektedir. Tablo 14 incelendiğinde $p<0,05$ anlamlık düzeyinde "Katılımcıların sosyal sorumluluk projelerinden haberdar oldukları iletişim mecralarına göre Eti Burçak ve WWF İşbirliği, Eti Çocuk Tiyatrosu, Eti Çocuk Vapuru sosyal sorumluluk projeleri farkındalık düzeyleri arasında anlamlı bir farklılık yoktur" denilebilir. Ancak $\mathrm{p}<0,05$ anlamlılık düzeyinde "katılımcıların sosyal sorumluluk projelerinden haberdar oldukları iletişim mecrasına göre Sarı bisiklet ve Çekül Kültür Elçileri sosyal sorumluluk projeleri farkındalık düzeyleri arasında anlamlı farklılık vardır" denilebilir. Sarı Bisiklet ve Çekül Kültür Elçileri projelerine ilisskin farkındalık ortalamaları incelendiğinde projelerden haberdar olunan internet ve televizyon mecralarının ortalamalarının gazete/ dergi, ürün ambalajları ve eş/dost ortalamalarına oranla daha yüksek olduğu görülmektedir. 
Aşağıda çalışmanın hipotez testlerine ilişkin Kabul/Red durumlarını gösteren özet tablo yer almaktadir.

\begin{tabular}{|c|c|c|c|c|c|}
\hline Hipotezler & & Kullanılan Analiz & $\mathbf{F}$ & $\mathbf{P}$ & KABUL/RED \\
\hline \multirow[b]{2}{*}{$\begin{array}{l}\mathrm{H}_{1} \text { : Sosyal medya } \\
\text { kullanıcılarının } \\
\text { cinsiyetlerine göre } \\
\text { marka farkındalığını } \\
\text { algılama düzeyleri ve } \\
\text { dolayısıyla da sosyal } \\
\text { sorumluluk projeleri } \\
\text { farkındalık düzeyleri } \\
\text { arasında farklılık } \\
\text { vardır. }\end{array}$} & $\begin{array}{c}\text { Marka } \\
\text { Farkındalıkları } \\
\text { Düzeyi }\end{array}$ & \multirow[b]{2}{*}{$\begin{array}{l}\text { Bağımsız } \\
\text { T-Testi }\end{array}$} & 2,030 & ,008 & \multirow[b]{2}{*}{ KABUL } \\
\hline & $\begin{array}{l}\text { Sosyal Sorumluluk } \\
\text { Projeleri } \\
\text { Farkındalıkları } \\
\text { Düzeyleri }\end{array}$ & & 3,031 & ,038 & \\
\hline \multirow{2}{*}{$\begin{array}{l}\mathrm{H}_{2} \text { : Sosyal medya } \\
\text { kullanıcılarının } \\
\text { yaşlarına göre marka } \\
\text { farkındalığını algılama } \\
\text { düzeyleri ve dolayısıyla } \\
\text { da sosyal sorumluluk } \\
\text { projeleri farkındalık } \\
\text { düzeyleri arasında } \\
\text { farklılık vardır. }\end{array}$} & $\begin{array}{c}\text { Marka } \\
\text { Farkındalıkları } \\
\text { Düzeyi }\end{array}$ & \multirow[b]{2}{*}{$\begin{array}{l}\text { Tek Yönlü } \\
\text { ANOVA }\end{array}$} & 4,150 & ,003 & \multirow[b]{2}{*}{ KABUL } \\
\hline & $\begin{array}{l}\text { Sosyal Sorumluluk } \\
\text { Projeleri } \\
\text { Farkındalıkları } \\
\text { Düzeyleri }\end{array}$ & & ,398 & ,008 & \\
\hline \multirow{2}{*}{$\begin{array}{l}\mathrm{H}_{3} \text { : Sosyal medya } \\
\text { kullanıcılarının eğitim } \\
\text { durumlarına göre } \\
\text { marka farkındalığını } \\
\text { algılama düzeyleri ve } \\
\text { dolayısıyla da sosyal } \\
\text { sorumluluk projeleri } \\
\text { farkındalık düzeyleri } \\
\text { arasında farklılık } \\
\text { vardır. }\end{array}$} & $\begin{array}{c}\text { Marka } \\
\text { Farkındalıkları } \\
\text { Düzeyi } \\
\end{array}$ & & 7,309 &, 001 & \multirow[b]{2}{*}{ KABUL } \\
\hline & $\begin{array}{c}\text { Sosyal Sorumluluk } \\
\text { Projeleri } \\
\text { Farkındalıkları } \\
\text { Düzeyleri }\end{array}$ & $\begin{array}{c}\text { Tek Yönlü } \\
\text { ANOVA }\end{array}$ & 1,235 & ,029 & \\
\hline \multirow[b]{2}{*}{$\begin{array}{l}\mathrm{H}_{4} \text { : Sosyal medya } \\
\text { kullanıcılarının gelir } \\
\text { düzeylerine göre } \\
\text { marka farkındalığını } \\
\text { algılama düzeyleri ve } \\
\text { dolayısıyla da sosyal } \\
\text { sorumluluk projeleri } \\
\text { farkındalık düzeyleri } \\
\text { arasında farklılık } \\
\text { vardır. }\end{array}$} & $\begin{array}{c}\text { Marka } \\
\text { Farkındalıkları } \\
\text { Düzeyi }\end{array}$ & \multirow[b]{2}{*}{$\begin{array}{c}\text { Tek Yönlü } \\
\text { ANOVA }\end{array}$} &, 755 &, 520 & \multirow[b]{2}{*}{ RED } \\
\hline & $\begin{array}{l}\text { Sosyal Sorumluluk } \\
\text { Projeleri } \\
\text { Farkındalıkları } \\
\text { Düzeyleri }\end{array}$ & & 3,448 & ,017 & \\
\hline \multirow{2}{*}{$\begin{array}{c}\mathrm{H}_{5} \text { : Sosyal medya } \\
\text { kullanıcılarının } \\
\text { sosyal sorumluluk } \\
\text { uygulamalarından } \\
\text { haberdar oldukları } \\
\text { iletişim mecrasına } \\
\text { göre marka } \\
\text { farkındalığını algılama } \\
\text { düzeyleri ve dolayısıyla } \\
\text { da sosyal sorumluluk } \\
\text { projeleri farkındalık } \\
\text { düzeyleri arasında } \\
\text { farklılık vardır. }\end{array}$} & $\begin{array}{c}\text { Marka } \\
\text { Farkındalıkları } \\
\text { Düzeyi } \\
\end{array}$ & \multirow[b]{2}{*}{$\begin{array}{l}\text { Tek Yönlü } \\
\text { ANOVA }\end{array}$} & ,795 & ,398 & \multirow[b]{2}{*}{ RED } \\
\hline & $\begin{array}{c}\text { Sosyal Sorumluluk } \\
\text { Projeleri } \\
\text { Farkındalıkları } \\
\text { Düzeyleri }\end{array}$ & & 1,019 & ,035 & \\
\hline
\end{tabular}

Tablo 15. Hipotez Testi Sonuçları 
Tablo 15'de sırasıyla araştırma hipotezleri, hipotezlerin test edilmesinde kullanılan analiz yöntemleri ve analiz sonucu yer almaktadir. Tablo 15 incelendiğinde çalışmanın kavramsal modeli kapsamında geliştirilen hipotezlerden H1: Sosyal medya kullanıcılarının cinsiyetlerine göre marka farkındalığını algılama düzeyleri ve dolayısıyla da sosyal sorumluluk projeleri farkındalık düzeyleri arasında farklılık vardır, H2: Sosyal medya kullanıcılarının yaşlarına göre marka farkındalığını algılama düzeyleri ve dolayısıyla da sosyal sorumluluk projeleri farkındalık düzeyleri arasında farklılık vardır, H3: Sosyal medya kullanıcılarının eğitim durumlarına göre marka farkındalığını algılama düzeyleri ve dolayısıyla da sosyal sorumluluk projeleri farkındalık düzeyleri arasında farklılık vardır $\mathrm{p}<0.05$ anlamlılık düzeylerinde kabul edildiği görülmektedir. "H4: Sosyal medya kullanıcılarının gelir düzeylerine göre marka farkındalığını algılama düzeyleri ve dolayısıyla da sosyal sorumluluk projeleri farkındalık düzeyleri arasında farklılık vardır”, "H5: Sosyal medya kullanıcılarının sosyal sorumluluk uygulamalarından haberdar oldukları iletişim mecrasına göre marka farkındalığını algılama düzeyleri ve dolayısıyla da sosyal sorumluluk projeleri farkındalık düzeyleri arasında farklılık vardır" hipotezlerinin $\mathrm{p}<0.05$ anlamlılık düzeylerinde kabul edilmediği görülmektedir. Dolayısıyla, "sosyal medya kullanıcılarının marka farkındalığı algılama düzeyleri ve sosyal sorumluluk projeleri farkındalık düzeylerinin demografik özelliklerden cinsiyet, yaş ve eğitim durumuna göre farklılık gösterdiği" ancak buna karş1lık "gelir düzeyi ile sosyal sorumluluk projelerinden haberdar olunan iletişim mecrasına göre farklılık göstermediği”" söylenebilir. Aşağıdaki bölümde çalışmanın analiz ve bulguları ayrıntılı olarak değerlendirilmektedir.

\section{v. SONUÇ}

Sosyal Sorumluluk projelerinin marka imajına olumlu katkılarda bulunmakta ve markaların farklı bir konuma sahip olmalarını sağlamakta olduğu bir gerçektir. Artan rekabet ortamı, ürünlerin zor geliştirilip kolay taklit edilebiliyor olması ve iletişimin son derece kolaylaşmış olması gibi günümüz koşulları dikkate alındığında markaların tüketiciler ve toplum ile diğer markalardan farklılaşan bir bağ kurmasını sağlayacak marka imajına sahip olmaları büyük önem taşımaktadır. Ancak bir markanın imajının değerlendirilebilmesi için tüketicilerin ilk önce o markanın farkında olması gerekir. Aynı şekilde sosyal sorumluluk projelerinin marka imajına olumlu katkılar yapabilmesi bu projelerin hangi markalar tarafından yürütüldüğünü bilinmesine bağlıdır. 
Çalışmanın amacı sosyal medya kullanıcılarının marka farkındalık düzeylerine göre sosyal sorumluluk projeleri farkındalık düzeyleri arasındaki farklılıkları incelemektir. Çalışmada bu amaçla demografik değişkenlerin yarattığı alg1 farklılıkları değerlendirilmiştir. Çalışmada, sosyal medya kullanıcılarının marka farkındalık düzeyi ve sosyal sorumluluk farkındalık düzeylerinin demografik faktörlere ve haberdar olunan iletişim mecralarına göre farklılık gösterdiği varsayılmaktadır. Çalışmanın amacı ve varsayımı kapsamında geliştirilen kavramsal modelin bağımsız değişkeni sosyal medya kullanıcılarının demografik özellikleri, aracı değişkeni ise sosyal medya kullanıcılarının marka farkındalıklarını algılama düzeyi farklılıkları olarak belirlenmiştir. Sosyal medya kullanıcılarının marka farkındalığ aracı değişkeni hatırlama, tanıma, bilgi, kanı ve baskınlık alt değişkenlerinden oluşmaktadır. Çalışmanın bağımlı değişkeni ise sosyal medya kullanıcılarının sosyal sorumluluk proje farkındalık düzeyi farklılıkları olarak belirlenmiştir. Çalışmanın amacı ve modeli kapsamında geliştirilen hipotezlerin analiz edilmesinde Bağımsız Örnelem T-Testi, One Way ANOVA Parametrik Testi ve Post-Hoc testleri kullanılmıştır.

Analiz sonuçları incelendiğinde sosyal medya kullanıcılarının demografik özelliklerinde cinsiyet, yaş ve eğitime ilişkin marka farkındalık düzeyleri ve sosyal sorumluluk kampanyaları farkındalık düzeyleri arasında anlamlı farklılıklar bulunmuştur. Dolayısıyla sosyal sorumluluk kampanyaları farkındalık düzeylerinin belirlenmesinde demografik özelliklerden cinsiyet, yaş ve eğitim durumuna göre farklılık gösterdiği söylenebilir. Cinsiyete göre marka farkındalığ farklılık düzeyinin tanıma ve kanı alt boyutlarından kaynaklandığı ve Eti Markasının sosyal sorumluluk projelerinden Sarı Bisiklet projesinin farkındalık düzeyinin de cinsiyete göre farklılık gösterdiği söylenebilir. Yaşa göre marka farkındalığı farklılık düzeyinin tanıma, baskınlık, bilgi ve kanı alt boyutlarından kaynaklandığı ve Eti Markasının sosyal sorumluluk projelerinden Eti Burçak WWF İşbirliği ve Eti Çocuk Tiyatrosu projelerinin farkındalık düzeyinin de yaşa göre farklılık gösterdiği söylenebilir. Eğitim durumuna göre marka farkındalığı farklılık düzeyinin tanıma, hatırlama, baskınlık ve kanı alt boyutlarından kaynaklandığı ve Eti Burçak WWF İşbirliği ve ÇEKÜL Kültür Elçileri projelerinin farkındalık düzeyinin de yaşa göre farklılık gösterdiği söylenebilir. Sosyal medya kullanıcılarının gelir düzeyi ve sosyal sorumluluk projelerinden haberdar oldukları iletissim mecrasına yönelik farklılıkların incelendiği analiz sonuçları incelendiğinde ise sosyal sorumluluk projeleri farkındalık düzeyleri arasında anlamlı farklılıklar olmasına rağmen marka farkındalık düzeyleri arasında anlamlı farklılıkların 
olmadığı belirlenmiştir Dolayısıyla sosyal medya kullanıcılarının sosyal sorumluluk proje farkındalık düzeyi farklılıklarında gelir düzeyi ve haberdar olunan iletişim mecrası değişkenlerinin etkili olmadığı sonucuna ulaşılmıştır.

Markalar sosyal sorumluluk projelerini gerçekleştirirken marka imajlarını olumlu yönde geliştirebilirler. Ancak yürütülen projelerin marka imajına katkı sağlayabilmesi için tüketicilerde marka farkındalık düzeyinin yüksek olması ve sosyal sorumluluk projelerinin hangi marka tarafindan yürütüldüğünün bilinilmesi gerekmektedir. Sosyal sorumluluk projelerinin farkındalığını artırıcı çalışmalarda marka ismi ve sosyal sorumluluk projesinin ismine yer verilerek marka imajına ve marka sadakatine katkı sağlanabilir.

Çalışma, aktif sosyal medya kullanıcılarını kapsamaktadır. Bu anlamda çalışmada kullanılan verilerin analiz sonuçları sosyal medya kullanıcılarının alg1 düzeyleri ile sınırlıdır. Çalışma, sosyal sorumluluk projelerinin algılanmasında, sosyal medya kullanıcılarının marka farkındalıklarının incelenmesi açısından özgün bir değer taşımaktadır.

\section{KAYNAKÇA}

AKKOYUNLU, G. Ş., ve Kalyoncuoğlu, S. (2014). İşletmelerin Kurumsal Sosyal Sorumluluk Çalışmalarının Marka Alg1sı Üzerine Etkisinin Değerlendirilmesi. Niğde Üniversitesi İktisadi ve İdari Bilimler Fakültesi Dergisi, Cilt7 Sayı, ss.125-144.

ANTALYALI, Ö. L. (2006). SPSS Uygulamalı Çok Değişkenli İstatistik Teknikleri, Ş.Kalaycı (Ed.), Ankara: Asil Yayın Dağıtım

BOLLEN, Kenneth A. (1989), Structural Equations With Latent Variables, John Wiley \& Sons Inc., New York, USA.

DENEÇLİ, S. (2015). Kurumsal Sosyal Sorumluluk Projelerinin Marka Farkındalığına Etkisi. İletişim Kuram ve Araştırma Dergisi, Sayı40, ss.315-328.

ELITOK, B. (2003), Hadi Markalaşalım. 1. Baskı. İstanbul: Sistem Yayıncılık.

ERDİL, T.S, Uzun, Y, Marka Olmak, 2. Baskı. İstanbul:Beta Yayıncılık.

FRANZEN, Giep. (1999). Brands \& Advertising. Kaynak: http://www.google.com.tr/ books?hl=tr\&lr=\&id=XkZRTiwa $1 \mathrm{~J} 0 \mathrm{C} \& \mathrm{oi}=$ fnd\&pg=PA8\&dq=giep+franzen + bran ds+advertising\&ots=7_bqXf0G-U\&sig=aIcxXUhXASNybj_oaiAVEUIp68s\&redir esc $=\mathrm{y} \# \mathrm{v}=$ onepage $\& \mathrm{q}=$ giep $\% 20$ franzen $\% 20$ brands $\% 20$ advertising $\& \mathrm{f}=$ false

HAIR, J.F., Anderson,R.E., Tatham, R.L., Black, W.C., (1998), Multivariate Data Analysis, Englewood Cliffs, NJ: PrenticeHall.

Eti Dünyas1 Etkinlikler http://www.etietieti.com/bizden_etkinlikler.aspx

İNCESU, Derya, Ç. (2011), Türkiye'deki Sosyal Sorumluluk Projelerinin Marka Farkındalığı Üzerindeki Etkileri, Haliç Üniversitesi, SBE, Yayınlanmamış Yüksek Lisans Tezi, İstanbul. 
İNTERNET VE SOSYAL MEDYA KULLANICI İSTATISTIIKLERI 2015, http://www. dijitalajanslar.com/internet-ve-sosyal-medya-kullanici-istatistikleri-2015/ Erişim Tarihi: 10.02.2016

İSLAMOĞLU, A.H. Fırat, D. (2011), Stratejik Marka Yönetimi, 2. Baskı, İstanbul: Beta Yayıncilik.

L'ETANG, J. ve Pieczka, M. (2002), Halkla İlişkilerde Eleştirel Yaklaşımlar, Ankara, Vadi Yayınları.

NAKİ, M. (2003), Pazarlama Araştırmaları Teknikler ve (Spss Destekli) Uygulamalar, Seçkin Yayıncılık, Ankara.

ÖLÇER, F. (2001). "Günümüzde Sosyal Sorumluluğun Değişen Boyutları ve İşletmeler Üzerine Etkileri”. Standart Dergisi, Y11: 40, Sayı: 473, TSE Yayınları, Mayıs 2001.

ÖZÇELIK, B. (2006), Spor Değil, Dizi Değil, Sosyal Projeler, http://www.halklailiskiler. com.tr/Spor_degildizi_degil..php Erişim Tarihi: 11.08.2016

POPE, N. (1998). "Consumption Values, Sponsorship Awareness, Brand and Products Use". Journal of Product and Brand Management. Santa Barbara. Cilt 7, Say1 2, ss.124-136

ŞENER, M. (1996), İşletmelerde Sosyal Sorumluluk, İstanbul Teknik Üniversitesi, FBE, Yayınlanmamış Yüksek Lisans Tezi, İstanbul.

TIĞLI, M. Pirtini, S. Çelik, C. (2006), 'Sosyal Sorumluluk Kampanyalarının Genç Tüketicilerin Marka Farkındalığı Üzerindeki Etkisinin İncelenmesine Yönelik Bir Araştırma', Marmara Üniversitesi Sosyal Bilimler Dergisi, İstanbul, Cilt7, Say127, ss.83-93.

TOPLU, S. (2009), Marka Farkındalığı Yaratma Sürecinde Kültür-Sanat Sponsorluk Etkinliklerinin İncelenmesi Ve Yorumlanmas1, Marmara Üniversitesi, SBE, Yayınlanmamış Yüksek Lisans Tezi, İstanbul.

TOSUn, B. N. (2010), İletişim Temelli Marka Yönetimi, Beta Basım Yayım Dağıtım, İstanbul, 1. Basım.

UZTUĞ, F. (2003), Markan Kadar Konuş, 2. Baskı. İstanbul: Mediacat Kitapları

YILDIRIM, Y. (2010),Popüler Televizyon Dizilerinin Ve Dizi Karakterlerinin Marka Farkındalığı Yaratmadaki Rolü, Kocaeli: Kocaeli Üniversitesi Sosyal Bilimler Enstitüsü, Yüksek Lisans Tezi. 